Part of Journal of Research of the National Bureau of Standards, Volume 19, July 1937

\title{
GASES IN SOME OPTICAL AND OTHER GLASSES
}

\author{
By Clarence Hahner, George Q. Voigt, and Alfred N. Finn
}

\section{ABSTRACT}

An apparatus and method for removing by vacuum fusion the gases dissolved in glass and for determining the quantity of gases are described. Determinations of gases in three types of optical glass and seven commercial glasses were made. Approximately the same quantities of water were found in the optical and the commercial glasses, but the total volume of other gases, such as $\mathrm{CO}_{2}, \mathrm{SO}_{2}, \mathrm{O}_{2}$, etc., never exceeded $10 \mathrm{ml}$ per $100 \mathrm{~g}$ of optical glass, while the window glass contained from 34 to $73 \mathrm{ml}$ per $100 \mathrm{~g}$ of glass. In the optical glasses, especially the light barium crown glass, there was no indication of a relation between the quantity of gas obtained and the number of "seeds" in the glass, nor was there any significant: change in the gas content of the glass during the stirring and fining periods.

\section{CONTENTS}

I. Introduction

II. Apparatus and procedure

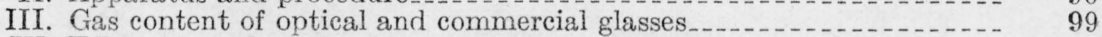

IV. Effect of condensed oxides_... 101

V. Effect of stirring and fining time

VI. Summary and conclusions

\section{INTRODUCTION}

It has been known for some time that all ordinary glasses when fused in a vacuum will yield gases that are either dissolved in the glass or formed by the decomposition of compounds that exist in the glass. This paper constitutes a report on the determination of the amounts and kinds of gases found in optical glasses and their bearing on the presence of "seeds" or small bubbles in the finished glass. Also, for comparison, the gases in some window glasses and tubing were determined.

Summaries of the methods for the determination of gases in glass, and the history of their development have been published by Dalton. ${ }^{1}$ and also by Salmang and Becker ${ }^{2}$ within the past few years. In all of the work that has been done on the extraction of gas from molten glass, the chief source of uncertainty has been the magnitude of the errors introduced by the absorption of gases by the alkaline materials that are volatilized from the molten glass. No method of eliminating this uncertainty has thus far been proposed, and little has been said as to just how large the error might be. The problems encountered in this respect are of major importance in the proper consideration: of the results obtained.

\footnotetext{
1 R. H. Dalton. Gases in glass. J. Am. Ceram. Soc. 16, 425 (1933); Extraction and analysis of gases from glass. J. Am. Chem. Soc. 57, 2150 (1935).

2 H. Salmang and A. Becker. Glastech. Ber. 5, 520 (1928); 6, 625 (1929); 7, 241 (1929).
} 


\section{APPARATUS AND PROCEDURE}

A diagrammatic sketch of the apparatus is shown in figure $1 .^{3}$ The apparatus consisted of a furnace in which the glass could be melted in a vacuum, an automatic sample-collecting pump of a type developed by Weaver and Shepherd, ${ }^{4}$ a weight burette ${ }^{5}$ for determining the volume of gas by weighing a quantity of mercury having an equal volume, and an Ascarite tube for absorbing the $\mathrm{CO}_{2}$.

The automatic sample-collecting pump consisted essentially of a mercury-vapor pump, a McLeod gage so arranged that it could be used to measure the pressure on either the high- or low-pressure side of the vapor pump, and an automatic Töpler pump for collecting the gas. Since the Töpler pump cannot be used to pump vapors that are readily condensable at room temperature, a weighing tube containing

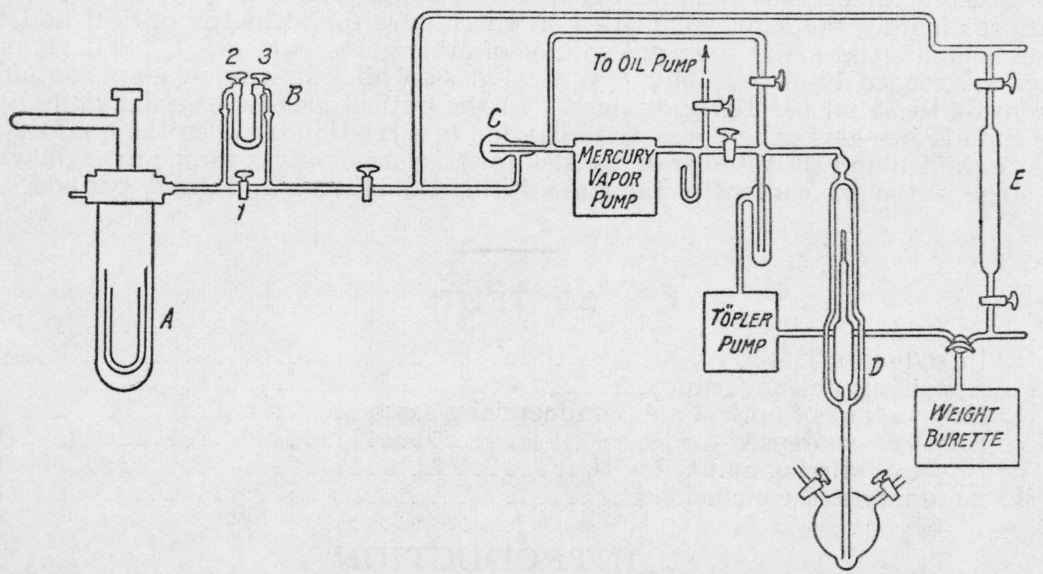

Figure 1.-Sketch of vacuum system.

$A$, vacuum furnace; $B$, weighing tube fllled with Dehydrite; $C$, drying bulb filled with Dehydrite; $D$, McLeod gage; $E$, Ascarite tube.

Dehydrite was placed between the furnace and the pump to absorb the water vapor.

A detailed sketch of the furnace is shown in figure 2. It consisted of a transparent fused-silica tube (24 cm long and $6 \mathrm{~cm}$ in diameter), inside of which was a smaller silica tube $(12$ by $4.5 \mathrm{~cm})$; inside the latter was the platinum crucible in which the glass was melted. The crucible and the two silica tubes were separated from each other by means of fused-silica supports.

The larger silica tube was closed at the top by a water-cooled brass cap having a fused-silica window in the top and a tube at the side to hold the glass sample and a piece of iron rod ( $A$, fig. 2$)$ during preliminary heating and degassing of the furnace. The iron rod, which could be actuated by a magnet, was used to push the glass forward until the sample dropped into the crucible.

\footnotetext{
3 Since this apparatus was constructed, Dalton described in the Journal of the American Chemical Society (see footnote 1) an apparatus which, because it has no stopcocks or greased or cemented joints in the part of $t$ he system used for collecting and analyzing the gases, should be free from some of the difficulties encountered in manipulating the apparatus described in this paper.

4 E. R. Weaver and M. Shepherd. An automatic sample-collecting vacuum pump. J. Am. Chem. Soc. ; 0, 1829 (1928).

5 E. R. Weaver and P. G. Ledig. A weight burette for gas analysis. J. Am. Chem. Soc. 42, 1177 (1920).
} 
The platinum crucible ( 9 by $3.7 \mathrm{~cm}$ ) had a capacity of $100 \mathrm{ml}$. This rather large capacity was necessary because of the frothing that took place when the glass was heated in a vacuum. As the heating was done by means of high-frequency induction, it was necessary that the walls of the platinum crucible be rather thick to prevent localized heating and consequent failure of the crucible. The walls of the crucible were about $1 \mathrm{~mm}$ in thickness.

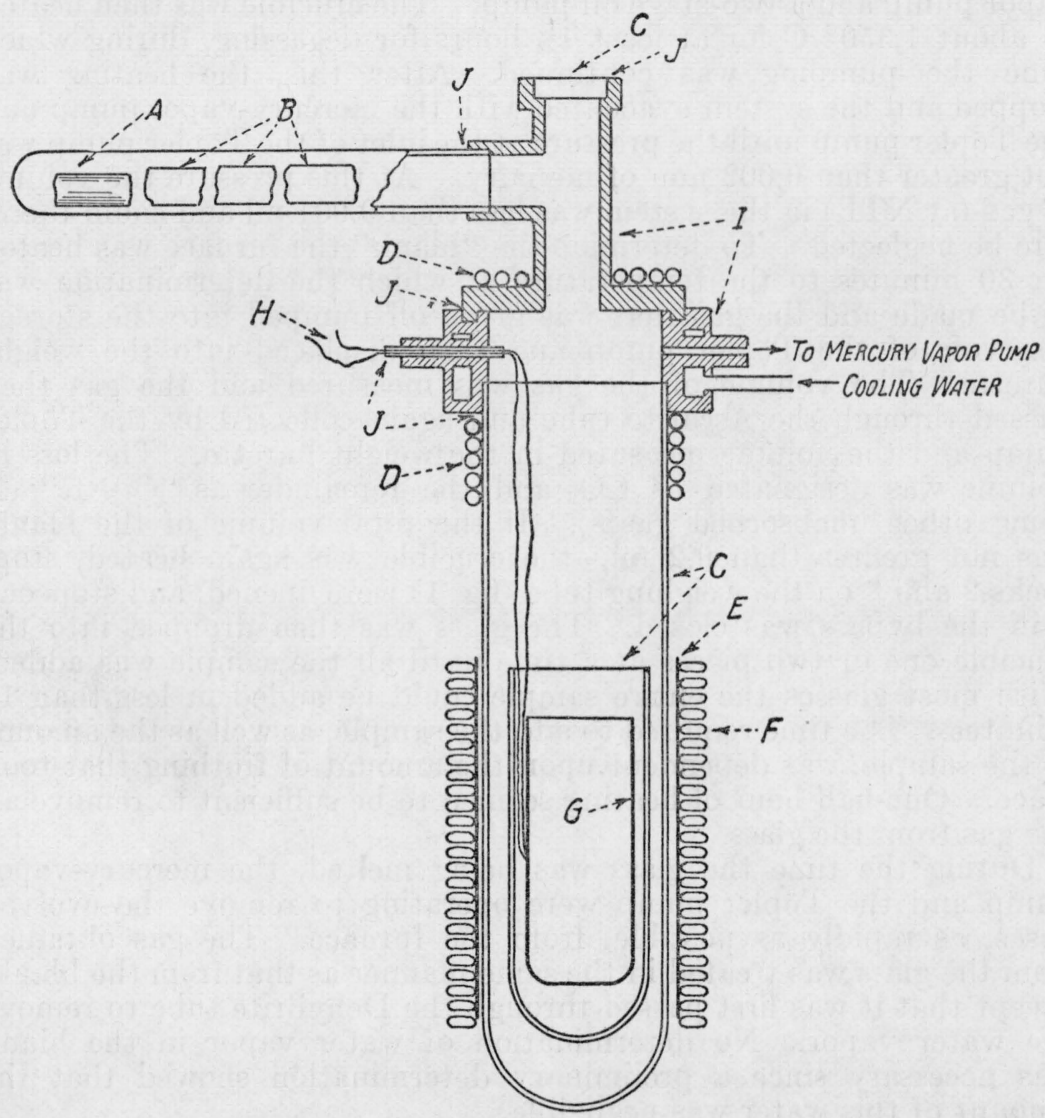

Figure 2.-Vacuum furnace.

$A$, iron rod; $B$, sample; $C$, fused silica; $D$, copper tubing for cooling water; $E$, sheet mica cylinder; $F$, inductor coil; $G$, platinum crucible; $H$, thermocouple; $I$, tinned brass cap and collar; $J$, Cementy te seals.

Energy for heating the platinum crucible was supplied by an Ajax 3 kva high-frequency converter and an inductor coil consisting of 50 turns of flattened copper tubing through which cooling water was circulated. The temperature was measured by a platinum-platinum10-percent-rhodium thermocouple. To insure good thermal contact, both wires of the thermocouple were welded directly to the platinum crucible. ${ }^{6}$

The operation of the apparatus can best be explained by following through the steps of a typical analysis. The weighed sample, which

\footnotetext{
- An attempt was made to determine the temperature of the glass with an optical pyrometer, but this was not successful because volatile oxides from the hot glass condensed on the window.
} 
consisted of five to eight pieces of glass (usually in the form of a rod), was cleaned with distilled water and alcohol, and heated to about $500^{\circ} \mathrm{C}$ in an electric muffle furnace to insure complete drying. Immediately after the sample was cold, it was placed in the sample tube, and the cap was sealed to the silica tube by means of Cementyte cement.

The furnace and the system were then evacuated, using the mercuryvapor pump and a two-stage oil pump. The crucible was then heated to about $1,350^{\circ} \mathrm{C}$ for at least $1 \frac{1}{2}$ hours for degassing, during which time the pumping was continued. After this, the heating was stopped and the system evacuated with the mercury-vapor pump and the Töpler pump until the pressure at the inlet of the Töpler pump was not greater than $0.002 \mathrm{~mm}$ of mercury. At this pressure the volume of gas (at NTP) in the system was less than $0.001 \mathrm{ml}$ and could therefore be neglected. To determine the "blank" the furnace was heated for 30 minutes to the temperature at which the determination was to be made and the gas that was given off pumped into the storage reservoir of the Töpler pump and then displaced into the weight burette. The volume of the gas was measured and the gas then passed through the Ascarite tube and again collected by the Töpler pump and the volume measured in the weight burette. The loss in volume was designated as $\mathrm{CO}_{2}$ and the remainder as " $\mathrm{O}_{2}+\mathrm{R}$ " ( $\mathrm{R}$ being other unabsorbed gases). If the total volume of the blank, was not greater than $0.2 \mathrm{ml},^{7}$ the crucible was again heated, stopcocks 2 and 3 on the weighing tube (fig. 1) were opened, and stopcock 1 in the bypass was closed. The glass was then dropped into the crucible one or two pieces at a time until all the sample was added. With most glasses the entire sample could be added in less than 15 minutes. The time required to add the sample, as well as the amount of the sample, was dependent upon the amount of frothing that took place. One-half hour of heating seemed to be sufficient to remove all the gas from the glass.

During the time the glass was being melted, the mercury-vapor pump and the Töpler pump were operating to remove the evolved gases, as rapidly as possible, from the furnace. The gas obtained from the glass was treated in the same manner as that from the blank, except that it was first passed through the Dehydrite tube to remove the water vapor. No determination of water vapor in the blank was necessary since a preliminary determination showed that the amount of this water was negligible.

After the furnace had been cut off from the rest of the system, the stopcocks on the weighing tube were closed, and the weighing tube was removed. The grease was carefully cleaned off the groundglass joints with petroleum ether and then with absolute alcohol, and the tube was weighed, using for a counterpoise a tube of like dimensions. The tube had been evacuated, cleaned, and weighed in a similar manner before the determination was started.

Before work was started on the glasses, some control determinations were made. A known quantity of $\mathrm{H}_{2} \mathrm{O}$ was added to the system by dropping a small thin-walled glass bulb containing a weighed quantity of water into the hot crucible. In two cases, 22.4 and $10.8 \mathrm{mg}$ of $\mathrm{H}_{2} \mathrm{O}$ were added and 21.1 and $10.6 \mathrm{mg}$ were found. A known quantity

7 Although the furnace was degassed for $11 / 2$ hours, it was sometimes necessary to further degas the furnace. until a satisfactory blank was obtained. When the value of the blank was $0.2 \mathrm{ml}$ or less, it was but little: reduced by further degassing up to 3 hours. 
of $\mathrm{CO}_{2}$ was added to the system by dropping a weighed piece of calcite into the crucible. In two cases, calcite equivalent to 4.40 and $4.09 \mathrm{ml}$ of $\mathrm{CO}_{2}$ was added and 4.41 and $4.12 \mathrm{ml}$ were found. These determinations were made under the same conditions as those used when a determination was made with a glass sample.

\section{GAS CONTENT OF OPTICAL AND COMMERCIAL GLASSES}

Determinations of the gases obtained by vacuum fusion of three types of optical glass and seven kinds of commercial tank glass were made. The averages of a number of determinations on each kind of glass and the compositions of the glasses are given in table 1 , in which all gas volumes were computed to volumes at normal temperature and pressure, the water being regarded as an ideal gas. ${ }^{8}$

In all the optical glasses water was by far the most abundant of the gases found. In most of the commercial tank glasses the quantities of " $\mathrm{CO}_{2}+\mathrm{SO}_{2}$ " and " $\mathrm{O}_{2}+\mathrm{R}$ " were materially greater than in the optical glasses. Chemical analyses of the commercial glasses showed that these glasses contained from 0.19 to 0.50 percent of $\mathrm{SO}_{3}$, which indicated they were made from batches containing sulphate. Since $\mathrm{SO}_{3}$ decomposes to $\mathrm{SO}_{2}$ and $\mathrm{O}_{2}$ at the temperature at which the vacuum fusion takes place, one might expect to obtain both $\mathrm{SO}_{2}$ and increased amounts of $\mathrm{O}_{2}$ from glass made from such batches. No separation of $\mathrm{SO}_{2}$ from $\mathrm{CO}_{2}$ was made and consequently any $\mathrm{SO}_{2}$ that might have been evolved is included with the $\mathrm{CO}_{2}$. The optical glasses were made from material that was almost free from sulphur compounds. Consequently, little $\mathrm{SO}_{2}$ would be expected.

To determine whether or not the amount of gas found was dependent upon the surface area, a sample of borosilicate crown glass was prepared, which had a much greater surface area than the usual sample. It consisted of particles of glass which passed a no. 10 and were retained on a no. 20 sieve. These particles were sintered together into the form of a rod so that the sample could be handled in the equipment, the temperature of sintering being only sufficiently high to make the particles stick together but not high enough to close any significant amount of the pore spaces. The sample was then treated in the usual manner, and no significant difference between the gas content of the original and the sintered samples was noted.

8 The apparatus for measuring and separating the gases could be made smaller for more accurate work since the volumes of gases obtained were less than was anticipated. 
TABLE 1.-Average values for volumes of gases obtained from glasses and composition of the glasses

OPTICAL GLASSES

\begin{tabular}{|c|c|c|c|c|c|c|c|c|c|c|c|c|c|c|c|c|c|}
\hline \multirow{2}{*}{ Glass 1} & \multirow{2}{*}{$\begin{array}{c}\text { Tem- } \\
\text { pera- } \\
\text { ture of } \\
\text { out- } \\
\text { gassing }\end{array}$} & \multicolumn{3}{|c|}{ Gas per $100 \mathrm{~g}$ of glass } & \multicolumn{13}{|c|}{ Composition of glass ${ }^{2}$} \\
\hline & & $\mathrm{H}_{2} \mathrm{O}$ & $\mathrm{O}_{2}+\mathrm{R}$ & $\mathrm{CO}_{2}+\mathrm{SO}_{2}$ & $\mathrm{SiO}_{2}$ & $\mathrm{CaO}$ & $\mathrm{MgO}$ & $\mathrm{Na}_{2} \mathrm{O}$ & $\mathrm{K}_{2} \mathrm{O}$ & $\mathrm{R}_{2} \mathrm{O}_{3}$ & $\mathrm{~B}_{2} \mathrm{O}_{3}$ & $\mathrm{ZnO}$ & $\mathrm{BaO}$ & $\mathrm{As}_{2} \mathrm{O}_{5}$ & $\mathrm{As}_{2} \mathrm{O}_{3}$ & $\mathrm{Sb}_{2} \mathrm{O}_{3}$ & $\mathrm{SO}_{3}$ \\
\hline $\begin{array}{l}\text { Borosilicate crown } A(2) \\
\text { Borosilicate crown } B(3)\end{array}$ & $\begin{array}{l}\circ \mathrm{C} \\
1,325 \\
1,345\end{array}$ & $\begin{array}{r}\mathrm{ml}_{49} \\
29\end{array}$ & $\mathrm{ml}_{0.2}$ & $\underset{0}{\mathrm{ml}}<0.1$ & $\begin{array}{r}\text { Percent } \\
65.6 \\
65.6\end{array}$ & Percent & Percent & $\begin{array}{r}\text { Percent } \\
7.9 \\
7.9\end{array}$ & \begin{tabular}{|c|} 
Percent \\
12.8 \\
12.8
\end{tabular} & Percent & $\begin{array}{c}\text { Percent } \\
11.4 \\
11.4\end{array}$ & $\begin{array}{c}\text { Percent } \\
1.8 \\
1.8\end{array}$ & Percent & $\begin{array}{c}\text { Percent } \\
0.40 \\
-\end{array}$ & $\begin{array}{c}\text { Percent } \\
0.03 \\
.5\end{array}$ & Percent & Percent \\
\hline Light barium crown $A(2) \ldots$ & $\left\{\begin{array}{l}1,350 \\
1,325\end{array}\right.$ & $\begin{array}{l}20 \\
31\end{array}$ & $\begin{array}{r}1.0 \\
.8\end{array}$ & $\begin{array}{l}0 \\
0\end{array}$ & 47.1 & 2.1 & & 1.9 & 7.7 & & 4.3 & 8.5 & 27.9 & .53 & .01 & & \\
\hline $\begin{array}{l}\text { Light barium crown } B(3) \\
\text { Light barium crown } C(2) \\
\text { Light crown } A(4)\end{array}$ & $\begin{array}{l}1,345 \\
1,345 \\
1,300 \\
1\end{array}$ & $\begin{array}{l}21 \\
17 \\
33 \\
38\end{array}$ & $\begin{array}{l}1.2 \\
1.1 \\
1.7\end{array}$ & $\begin{array}{r}.7 \\
<.1 \\
4.0\end{array}$ & $\begin{array}{l}46.6 \\
46.9 \\
71.0 \\
71.0\end{array}$ & 13.1 & $\mid$ & $\begin{array}{r}.5 \\
15 \\
15.4 \\
15.4\end{array}$ & $\begin{array}{l}7.1 \\
7.1\end{array}$ & 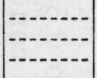 & $\begin{array}{r}3.7 \\
3.7 \\
\hdashline\end{array}$ & $\begin{array}{r}7.8 \\
7.9 \\
-\end{array}$ & $\begin{array}{r}33.7 \\
33.2 \\
-\end{array}$ & . & $\begin{array}{l}.6 \\
.2 \\
.01 \\
5\end{array}$ & 0.5 & \\
\hline Light crown $B(1)$ & 1,350 & 38 & 5.4 & 4.1 & 71.0 & 13.1 & $\mid-\ldots+\ldots$ & 15.4 & 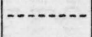 & & $\mid-\ldots+2$ & & - & & & & \\
\hline
\end{tabular}

COMMERCIAL GLASSES

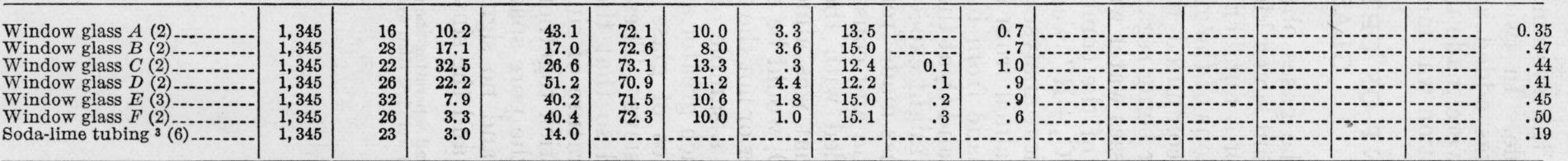

1 The letters in this column indicate separate melts of glass in the optical group and glasses from different factories in the commercial group. The number in parentheses indicates the number of determinations on which the average is based.

determined by routine analysis. The compositions of the optical glasses were calculated from the batch composition except for the oxides of arsenic when values are given for both $\mathrm{As}_{3} \mathrm{O}_{3}$ and $\mathrm{As}_{2} \mathrm{O}_{3}$. In these cases the arsenic was determined analytically. The batch materials used in making the optical glasses were practically free from sulphur compounds.

3 Not analyzed except for $\mathrm{SO}_{3}$. 
TABLE 2.-Variation in individual determinations on light crown optical glass

[All determinations made at $1,300^{\circ} \mathrm{C}$ and on samples from the same melt]

\begin{tabular}{|c|c|c|c|c|c|c|c|c|}
\hline \multirow{2}{*}{ Weight of sample } & \multicolumn{3}{|c|}{$\begin{array}{l}\text { Amounts of gases ob- } \\
\text { tained }\end{array}$} & \multicolumn{2}{|c|}{ Blank } & \multicolumn{3}{|c|}{ Gas per $100 \mathrm{~g}$ of glass } \\
\hline & $\mathrm{H}_{2} \mathrm{O}$ & $\mathrm{O}_{2}+\mathrm{R}$ & $\mathrm{CO}_{2}$ & $\mathrm{O}_{2}+\mathrm{R}$ & $\mathrm{CO}_{2}$ & $\begin{array}{c}\mathrm{H}_{2} \mathrm{O} \text { as } \\
\text { gas }\end{array}$ & $\mathrm{O}_{2}+\mathrm{R}$ & $\therefore \mathrm{CO}$ \\
\hline $\begin{array}{c}\text { g } \\
20.54 \\
24.09 \\
21.34 \\
22.50\end{array}$ & $\begin{array}{l}\mathrm{g} \\
0.0057 \\
.0067 \\
.0042 \\
.0068\end{array}$ & $\begin{array}{l}\mathrm{ml} \\
0.38 \\
.46 \\
: 43 \\
.70\end{array}$ & $\begin{array}{l}\mathrm{ml} \\
1.21 \\
.92 \\
.66 \\
.83\end{array}$ & $\begin{array}{l}\mathrm{ml} \\
0.18 \\
.18 \\
.08 \\
.06\end{array}$ & $\begin{array}{l}\mathrm{ml} \\
0.02 \\
.04 \\
.03 \\
.02\end{array}$ & $\begin{array}{r}\mathrm{ml} \\
34 \\
35 \\
25 \\
38\end{array}$ & $\begin{array}{c}\mathrm{ml} \\
1.0 \\
1.2 \\
1.6 \\
2.8\end{array}$ & $\begin{array}{r}\mathrm{m}] \\
5 . \\
3 . \\
3 . \\
3 .\end{array}$ \\
\hline
\end{tabular}

a Since the amount of sulphate in the batch material from which this glass was made was very small, $t$ he gas absorbed by the Ascarite was considered to be entirely $\mathrm{CO}_{2}$.

\section{EFFECT OF CONDENSED OXIDES}

Table 2 gives the results of four separate determinations made at $1,300^{\circ} \mathrm{C}$ on light crown optical glass.

There is considerable variation in the amounts found of any given constituent, and this can be explained only as arising from the method used for vacuum fusion, since $\mathrm{jt}$ is not reasonable to assume that there was a significant difference in the glass itself as the samples were all taken from the same large piece. The chief source of error is undoubtedly the absorption of the evolved gases by the volatilized oxides (such as those of sodium, boron, etc.) which condense on the colder portions of the vacuum furnace. Indeed, it seems that this absorption is so important that it outweighs any other sources of error that might exist. In all the determinations that were made the presence of condensed oxides was observed.

To determine how much absorption takes place under extremely adverse conditions, two determinations were made on a soda-limesilica glass, the first portion of the sample being completely outgassed before the second portion was added. The furnace and crucible were not cleaned between the first and second heatings. In order that the water-absorption tube might be removed for weighing the water from the first portion of the sample, dry air was admitted to the furnace. This made it necessary to degas the furnace again. The first portion of the glass was, therefore, heated in the crucible for a total of 2 hours before the second portion of the sample was added. Since, under these conditions, no measurable quantity of gas was obtained from the second portion, the gas evolved must have been entirely absorbed by the condensed oxides volatilized during the first part of the test.

TABLE 3.-Effect of condensed oxides on amounts of gases obtained from soda-lime tubing glass

\begin{tabular}{|c|c|c|c|c|c|c|c|}
\hline \multirow{2}{*}{ Sample 1} & \multirow{2}{*}{$\begin{array}{c}\text { Weight of } \\
\text { glass }\end{array}$} & \multirow{2}{*}{$\mathrm{H}_{2} \mathrm{O}$} & \multirow{2}{*}{$\mathrm{O}_{2}+\mathrm{R}$} & \multirow{2}{*}{$\mathrm{CO}_{2}$} & \multicolumn{3}{|c|}{ Gas per $100 \mathrm{~g}$ of glass } \\
\hline & & & & & $\mathrm{H}_{2} \mathrm{O}$ & $\mathrm{O}+\mathrm{R}$ & $\mathrm{CO}_{2}$ \\
\hline $\begin{array}{l}A_{1} \\
A_{2} \\
B_{1} \\
B_{2}\end{array}$ & $\begin{array}{l}\text { g } \\
7.11 \\
5.62 \\
8.28 \\
6.50\end{array}$ & $\begin{array}{l}\mathrm{ml} \\
2.0 \\
0 \\
1.7 \\
0\end{array}$ & $\begin{array}{c}\mathrm{ml} \\
0.04 \\
.07\end{array}$ & $\begin{array}{l}\mathrm{ml} \\
0.62 \\
0 \\
1.13 \\
0\end{array}$ & $\begin{array}{r}\mathrm{ml} \\
28 \\
0 \\
21 \\
0\end{array}$ & $\begin{array}{l}\mathrm{ml} \\
0.6 \\
0 \\
0\end{array}$ & $\begin{array}{l}\mathrm{ml} \\
8.7 \\
0.7 \\
13.7 \\
0\end{array}$ \\
\hline
\end{tabular}

${ }^{1} A_{1}$ and $A_{2}$ and also $B_{1}$ and $B_{2}$ are the first and second portions, respectively, of the sample used in 1 determination. 
These data are given in table 3 and indicate that in any series of determinations on one glass even the highest values obtained may be far too low. The amount of absorption by condensed oxides will depend, among other things, on the composition of the glass, the temperature at which the vacuum fusion takes place, the rate at which the gases are removed from the furnace, and the shape and volume of the furnace.

\section{ERFECT OF STIRRING AND FINING TIME}

In table 4 are given the results obtained on samples taken from pots of optical glass at intervals during the stirring and fining periods. The total time taken for stirring ${ }^{9}$ the glass and the time and temperature at which the melt was sampled are indicated.

There was apparently no significant change in the gas content after the batch was completely melted and stirring had been started, the carbon dioxide and oxygen being entirely eliminated, or nearly so, and the water content reaching a constant value during the early stages of the melt. Since the optical glass had been vigorously stirred, it was to be expected that an equilibrium between the carbon dioxide and water in the glass and in the furnace atmosphere would be reached more rapidly than when the glass is not stirred, as in ordinary commercial practice. The stirring may also explain why we found much less oxygen in the light crown optical glass containing arsenic than Dalton ${ }^{10}$ found in a glass of similar composition.

TABLE 4.-Gases obtained from samples of optical glass taken at various times during the melting period

BOROSILICATE CROWN GLASS $B$

\begin{tabular}{|c|c|c|c|c|}
\hline \multirow{2}{*}{$\begin{array}{l}\text { Tempera- } \\
\text { ture of } \\
\text { melt when } \\
\text { sample was } \\
\text { taken. }\end{array}$} & \multirow{2}{*}{$\begin{array}{c}\text { Time be- } \\
\text { tween start } \\
\text { of stirring } \\
\text { and taking } \\
\text { of sample } \\
\text { for test. }\end{array}$} & \multicolumn{3}{|c|}{ Gas per $100 \mathrm{~g}$ of glass } \\
\hline & & $\mathrm{H}_{2} \mathrm{O}$ & $\mathrm{O}_{2}+\mathrm{R}$ & $\mathrm{CO}_{2}$ \\
\hline $\begin{array}{l}{ }^{\circ} \mathrm{C} \\
1,400 \\
1,400 \\
1,275 \\
1,275 \\
(\mathrm{a})\end{array}$ & $\begin{array}{r}\text { hr } \\
1.5 \\
3.0 \\
7.5 \\
11.5 \\
14.0\end{array}$ & $\begin{array}{c}\mathrm{ml} \\
45 \\
28 \\
32 \\
34 \\
29\end{array}$ & $\begin{array}{l}\mathrm{ml} \\
0 \\
0 \\
0 \\
0 \\
0\end{array}$ & $\begin{array}{r}\mathrm{ml} \\
0 \\
0 \\
0 \\
0 \\
0\end{array}$ \\
\hline \multicolumn{5}{|c|}{ LIGHT BARIUM CROWN GLASS $C$} \\
\hline $\begin{array}{l}1,360 \\
1,360 \\
1,295 \\
\text { (a) }\end{array}$ & $\begin{array}{r}7.0 \\
9.0 \\
12.5 \\
16.0\end{array}$ & $\begin{array}{l}15 \\
23 \\
17 \\
17\end{array}$ & $\begin{array}{l}2.7 \\
2.0 \\
2.5 \\
1.1\end{array}$ & $\begin{array}{l}0 \\
0 \\
0.3 \\
<.1\end{array}$ \\
\hline \multicolumn{5}{|c|}{ LIGHT CROWN GLASS $B$} \\
\hline $\begin{array}{l}1,410 \\
1,410 \\
1,375 \\
1,350 \\
(\mathrm{a})\end{array}$ & $\begin{array}{r}1.0 \\
4.0 \\
8.0 \\
12.0 \\
\text { b } 13.0\end{array}$ & $\begin{array}{l}28 \\
35 \\
33 \\
29 \\
38\end{array}$ & $\begin{array}{l}6.0 \\
5.4 \\
6.9 \\
5.5 \\
5.4\end{array}$ & $\begin{array}{l}3.0 \\
3.0 \\
2.2 \\
5.1 \\
4.1\end{array}$ \\
\hline
\end{tabular}

a Finished glass. The sample for this test was taken after the glass had cooled.

- Indicates the time between the start of stirring and the removal of the pot from the furnace.

- Stirring was started about 1 hour after the last batch fill.

10 R. H. Dalton. J. Am. Ceram. Soc. 16, 425 (1983). 


\section{SUMMARY AND CONCLUSIONS}

An apparatus and procedure for extracting and measuring the gases obtained from molten glass are described. Measurements of dissolved gases were made on 14 glasses representing 3 types of optical glass and 7 commercial tank glasses. Water was the most abundant gas in the optical glasses, while the commercial tank glasses, all of which contained sulphur compounds, yielded appreciable quantities of " $\mathrm{SO}_{2}+\mathrm{CO}_{2}$ " and " $\mathrm{O}_{2}+\mathrm{R}$ " in addition to water in amounts comparable to that in the optical glasses. The total volume of gases extracted from the glass was from one-half to several times the volume of the glass itself.

The method used for extracting and measuring the gas has given only fairly reproducible results, and it is thought that all results are low because of absorption of the gases by the oxides from the glass that condense in the upper portion of the furnace. This absorption could probably be lowered by redesigning the apparatus in such a way that the gases could be more rapidly removed from the furnace.

Since the amount of gas obtained from all the optical glasses was relatively small in comparison with that obtained from window glass, and since all the glasses except the light barium crown were relatively free from seeds, there is probably no relation between dissolved gas and the prevalence of seeds in the light barium crown. Furthermore, there was no significant difference in the amounts of gases obtained from samples taken at intervals during the stirring and fining periods, although the seeds decreased materially in size and number during these periods.

Washington, May 11, 1937. 